\title{
REMOVAL BESI, MANGAN DAN ZAT ORGANIK DALAM AIR TANAH DENGAN MULTIPLE TRAY AERATOR MENGGUNAKAN MEDIA KONTAK ARANG DAN BATU KERIKIL
}

\author{
Nindya Yusniartanti ${ }^{1)}$, dan Hari Wiko Indaryanto ${ }^{2)}$ \\ ${ }^{1)}$ Program Studi Teknik Sipil, Universitas Nahdlatul Ulama, Blitar, Jawa Timur \\ ${ }^{2)}$ Departemen Teknik Lingkungan, Institut Teknologi Sepuluh Nopember, Surabaya, Indonesia \\ e-mail: nindyayusniar@gmail.com ${ }^{1)}$
}

\begin{abstract}
ABSTRAK
Sumber air baku di PDAM Kota Blitar diambil dari air tanah dalam (sumur bor). Khusus untuk sumur bor yang berlokasi di Kelurahan Gedog, Kota Blitar, kualitas air baku secara fisik dan biologis telah memenuhi persyaratan, tetapi secara kimia belum memenuhi. Konsentrasi besi (Fe) dalam air baku yang terkandung mencapai 0,536 mg/L. Berdasarkan Keputusan Menteri Kesehatan RI Nomor 907/MENKES/VII/2002 syarat maksimal kandungan Fe-nya harus dibawah 0,3 mg/L.

Penelitian dibatasi pada pembuatan suatu unit aerasi tray aerator dalam skala laboratorium. Dalam penelitian dilakukan variasi jumlah tray, yaitu 2 tray dan 3 tray; jenis media kontak, yaitu media arang dan media batu kerikil.

Berdasarkan penelitian, efisiensi removal tertinggi untuk semua parameter diperoleh dari hasil variasi dengan jumlah tray 3 tingkat dan jenis media kontak arang, yaitu diperoleh efisiensi removal sebesar 83,96\% untuk removal Fe, 32,43\% untuk removal Mn, dan 21,43\% untuk removal zat organik.
\end{abstract}

Kata Kunci: Kerikil, Arang, Tray Aerator, Air Tanah

\begin{abstract}
Source of standard water in PDAM of Blitar City had taken away from ground water (well drill). Specially for Gedog's well drill, the quality of standard water for physical and biological parameter have fulfilled conditions, but for chemical parameter not yet fulfilled. Iron concentration $\left(\mathrm{Fe}^{2+}\right.$ ) in standard water amount $0,536 \mathrm{mg} / \mathrm{L}$.

Research limited by making an unit of aeration process such as tray aerator in laboratory scale. Research conducted by variation amount of tray, 2 tray and 3 tray, and variation of contact media type, there is charcoal and gravel for both amount of tray aerator.

The highest result of these research for all parameter obtained from result of variation with amount of 3 tray and media contact charcoal, with efficiency of removal equal to $83,96 \%$ for the removal of Fe, 32,43\% for the removal of Mn, and $21,43 \%$ for the removal of an organic matter.
\end{abstract}

Keywords: Gravel, Charcoal, Tray Aerator, Groundwater

\section{PENDAHULUAN}

$\mathrm{S}$

UMBER air baku di PDAM Blitar yang mengambil dari air tanah dalam, secara fluktuatif memiliki kandungan besi-mangan melebihi standar maksimum yang dianjurkan. Berdasarkan data sekunder yang diperoleh, kadar besi dalam air baku PDAM Blitar memiliki konsentrasi besi (Fe) 0,53 mg/L dan mangan (Mn) 0,03 $\mathrm{mg} / \mathrm{L}$.

Dengan adanya kandungan besi $(\mathrm{Fe})$ yang melebihi standar maksimum yang dianjurkan, maka perlu dipertimbangkan upaya pengendalian kualitas air dengan prinsip biaya serendah mungkin dengan hasil yang optimum. yaitu melalui proses aerasi menggunakan tray bertingkat. Oksigen yang tersedia di udara bebas, menyebabkan biaya operasional menjadi murah. Tujuan dari pelaksanaan penelitian adalah mengetahui keefektifan metode penurunan besi ( $\mathrm{Fe}$ ) dengan menggunakan tray bertingkat serta hubungan penurunan besi $(\mathrm{Fe})$ dengan variasi jumlah tray dan jenis media kontak (arang dan batu).

Ruang lingkup dalam penelitian meliputi penelitian dilakukan menggunakan model tray aerator skala laboratorium. Dimana sampel yang digunakan berupa sampel asli yang kondisinya alami dan berasal dari sumur bor yang dimiliki oleh PDAM Kota Blitar. Setelah itu dilakukan percobaan dengan pengaturan variasi jumlah tray dan variasi jenis media kontak dan dilanjutkan dengan pengendapan/sedimentasi.

Parameter yang diukur adalah kadar Fe total, kadar Mn total, zat organik (PV) total, kekeruhan, pH serta temperatur, kemudian dianalisa dan dibandingkan tingkat efisiensi removal kadar Fe, Mn, dan zat organik pada media arang dan media batu, dengan jumlah tray yang berbeda terhadap kualitas air bersih yang dihasilkan. 


\section{LANDASAN TEORI}

\section{- Besi dan Mangan Dalam Air}

Besi dan mangan merupakan unsur pokok alamiah dari tanah dan batu-batuan. Keberadaan besi dalam air tanah biasanya berhubungan dengan pelarutan batuan dan mineral terutama oksida, sulfida, karbonat, dan silikat yang mengandung logam-logam tersebut. Variasi besi dan mangan ini menerangkan kenyataan bahwa cairan yang mengandung besi dan mangan yang soluble (dapat larut) umumnya memiliki kadar besi yang lebih besar daripada kadar mangannya. Jarang ditemukan cairan yang memiliki kadar besi yang lebih besar dari $10 \mathrm{mg} / \mathrm{L}$ ataupun kadar mangan yang lebih besar dari $2 \mathrm{mg} / \mathrm{L}$. Pada umumnya besi dalam air dapat bersifat :

- $\quad$ Terlarut sebagai $\mathrm{Fe}^{2+}$ (ferro) atau $\mathrm{Fe}^{3+}$ (ferri)

- Tersuspensi sebagai butir koloidal (diameter $<1 \mu \mathrm{m}$ ) atau yang lebih besar seperti $\mathrm{Fe}_{2} \mathrm{O}_{3}, \mathrm{FeO}, \mathrm{Fe}(\mathrm{OH})_{3}$ dan sebagainya.

- Tergabung dengan zat organis atau zat padat yang inorganik seperti tanah liat

Pada air permukaan jarang ditemui kadar Fe lebih besar dari $1 \mathrm{mg} / \mathrm{L}$, tetapi dalam air tanah kadar Fe dapat jauh lebih tinggi. Konsentrasi Fe yang tinggi ini dapat dirasakan dan dapat menodai kain, perkakas dapur, dan alat sanitair. Sedangkan pada air tanah yang memiliki alkalinitas yang tinggi biasanya memiliki konsentrasi besi yang rendah karena besi teroksidasi dan mengendap pada $\mathrm{pH}$ yang tinggi (basa). Air tanah mengandung besi dan bahan organik yang tinggi akan membentuk ikatan kompleks yang sulit mengendap dengan aerasi. (Qasim, et al, 2000)

Pada air yang tidak mengandung oksigen $\left(\mathrm{O}_{2}\right)$, seperti sering kali air tanah, besi berada sebagai $\mathrm{Fe}^{2+}$ yang cukup dapat terlarut. Sedangkan pada air sungai yang mengalir dan terjadi aerasi, $\mathrm{Fe}^{2+}$ teroksidasi menjadi $\mathrm{Fe}^{3+}, \mathrm{Fe}^{3+}$ ini sulit larut pada $\mathrm{pH}$ 6-8 bahkan dapat menjadi ferri hidroksida $\left(\mathrm{Fe}(\mathrm{OH})_{3}\right)$ atau salah satu jenis oksida yang merupakan zat padat $\mathrm{Fe}^{3+}$ terlarut, dan $\mathrm{Fe}^{3+}$ dalam bentuk senyawa-senyawa organik berupa koloidal. (G. Alaerts, 1987)

Kehadiran besi dalam air perlu dideteksi, karena pengendapan logam tersebut merubah warna/penampakan air, berkisar kuning kecoklatan sampai hitam. Lagipula, akumulasi endapan tersebut akan mengotori atau merusak perlengkapan pipa ledeng dan pakaian atau cucian.

Karena kondisi yang merugikan akibat logam besi ini, maka EPA menyarankan agar konsentrasi besi dalam air minum, tidak lebih dari $0,3 \mathrm{mg} / \mathrm{L}$ dan dalam air bersih tidak boleh lebih dari $1 \mathrm{mg} / \mathrm{L}$. Segala air yang konsentrasi besinya lebih dari yang telah disarankan, harus dipertimbangkan untuk membuang atau menguranginya. Sedangkan untuk kandungan mangan maksimum dalam air minum menurut EPA maksimum 0,05 mg/L. (Qasim,et.al., 2000)

Terdapat tiga metode yang biasa digunakan untuk mengontrol kehadiran Fe dalam penyediaan air minum yaitu presipitasi yang diikuti dengan filtrasi, ion exchange (pertukaran ion), dan stabilisasi besi dalam larutan dan zatzat pendispersi untuk mencegah terjadinya endapan dari logam-logam tersebut. (Benefield, 1982)

\section{- Multiple Tray Aerator}

Aerator jenis ini terdiri dari seri tray yang dilengkapi dengan plat berlubang yang saling berhubungan dengan alasnya yang mampu mendistribusikan dan menjatuhkan air dalam bak penampung dibawahnya, dan biasanya digunakan untuk menurunkan kadar besi (Fe) dan mangan (Mn) dengan konsentrasi antara 5-10 mg/L.

Pada umumnya jumlah tray yang dipakai adalah 3 sampai dengan 5 tray, dengan jarak antar tray 13 - 30 in, sedang bahan yang dipakai bisa digunakan dari stainless steel, alumunium dan kayu. Bentuk dari tray aerator dapat dilihat pada Gambar 1.
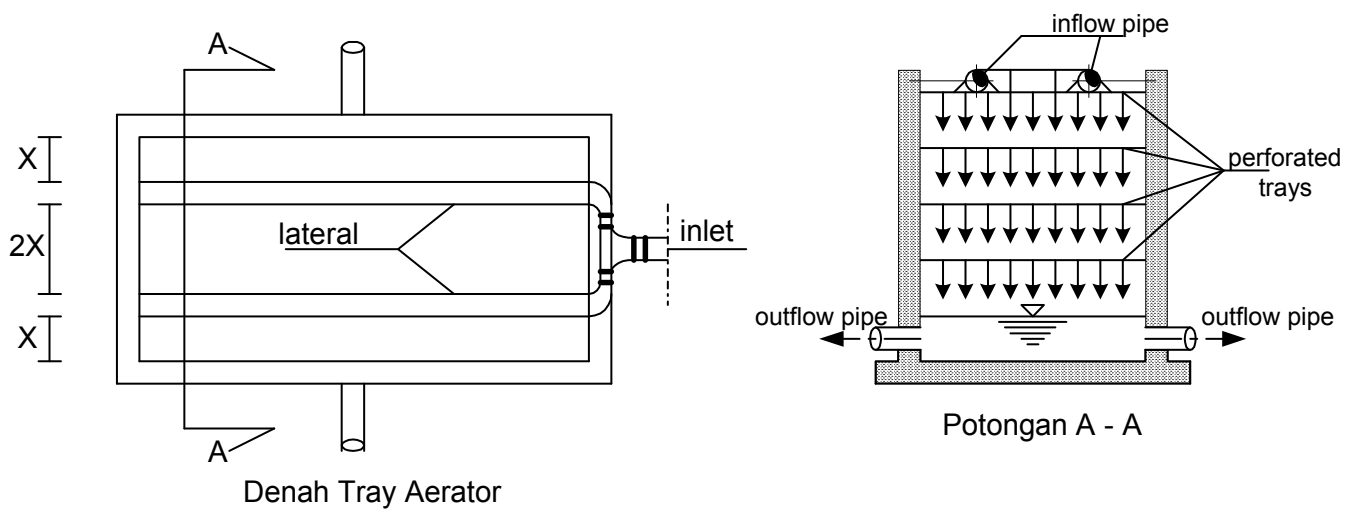

Gambar 1. Denah dan potongan unit tray aerator 
Didalam multiple tray aerator sering ditambahkan media kasar seperti batu, batubara, atau keramik dengan ukuran $2-6$ in yang ditempatkan pada permukaan tray dengan tujuan untuk memperbaiki efisiensi perpindahan gas, penyebaran air dan tempat yang menguntungkan sebagai efek katalisa penurunan dalam oksida mangan.

\section{- Transfer Oksigen dan Aerasi}

Transfer suatu material yang mudah menguap (volatile) ke atau dari air melalui proses aerasi tergantung pada sejumlah faktor, antara lain: (Degremont, "Water Treatment Handbook")

- Karakteristik dari material yang mudah menguap (volatile)

- Air dan temperatur udara sekitar

- Pengganggu dalam proses perpindahan gas

- Tegangan sebagian gas di (dalam) aerator atmosphir

- Turbulensi di dalam dan fase gas dan cair

- Perbandingan antara volume dan area

- Waktu ekspose

\section{METODOLOGI PENELITIAN}

Penelitian dilakukan dengan menggunakan unit tray aerator skala laboratorium yang dijalankan secara kontinyu. Selanjutnya dilakukan pengambilan sampel berdasarkan variasi yang telah ditentukan, baik pada inlet maupun outlet tray aerator.

Sampel yang telah diambil selanjutnya dianalisa di laboratorium hingga didapatkan data hasil pengukuran untuk seluruh parameter dari masing-masing variabel penelitian. Kemudian data penelitian dibahas dan dikaji berdasarkan literatur, sehingga diperoleh simpulan data hasil penelitian.

Variasi penelitian pada unit aerasi-multiple tray aerator tanpa adanya media kontak digunakan sebagai variabel kontrol, yang berfungsi sebagai pembanding, sehingga dapat diketahui seberapa besar tingkat efektifitas penambahan media kontak pada unit aerasi. Sedangkan variasi jenis media kontak bertujuan untuk mengetahui pengaruh jenis media kontak (arang dan batu kerikil) terhadap proses aerasi yang terjadi dalam menurunkan kandungan besi $\left(\mathrm{Fe}^{2+}\right)$ terlarut.

\section{HASIL DAN PEMBAHASAN}

\section{- Hasil Analisa dan Pembahasan Tiap Parameter Sampel Pada Tray Aerator Tanpa Media Kontak, seba- gai Variabel Kontrol \\ - Removal Fe}

Berdasarkan Tabel 1 dapat diketahui bahwa removal $\mathrm{Fe}^{2+}$ pada tray aerator tanpa adanya media kontak dalam penelitian ini memiliki efisiensi removal sebesar 33,77\% atau sebanding dengan $0,181 \mathrm{mg} / \mathrm{L} \mathrm{Fe}$ pada jumlah tray 2 tingkat, dan 50,75\% atau sebanding dengan $0,272 \mathrm{mg} / \mathrm{L}$ Fe pada jumlah tray 3 tingkat.

Tabel 1. Data pengujian parameter Fe pada tray tanpa media kontak

\begin{tabular}{ccc}
\hline Jumlah Tray & Inlet $\left(\mathbf{m g} / \mathbf{L ~} \mathbf{F e}^{2+}\right)$ & Outlet $\left(\mathbf{m g} / \mathbf{L ~} \mathbf{F e}^{\mathbf{3 +}}\right)$ \\
\hline outlet 2 tray & 0,536 & 0,355 \\
outlet 3 tray & & 0,264 \\
\hline
\end{tabular}

Sumber: Hasil Analisa Laboratorium

Dari hasil tersebut dapat diketahui bahwa efisiensi removal $\mathrm{Fe}^{2+}$ akan meningkat seiring dengan bertambah banyaknya jumlah tray yang digunakan. Hal ini disebabkan karena dengan bertambah banyaknya jumlah tray yang digunakan, maka waktu kontak antara air dengan oksigen di udara akan semakin lama, sehingga memungkinkan oksigen terlarut dalam air akan semakin besar pula. Oksigen terlarut inilah yang nantinya berperan dalam proses oksidasi $\mathrm{Fe}^{2+}$ menjadi $\mathrm{Fe}^{3+}$ yang dapat mengendap, sesuai dengan reaksi oksidasi sebagai berikut :

$$
4 \mathrm{Fe}\left(\mathrm{HCO}_{3}\right)_{2}+\mathrm{O}_{2}+2 \mathrm{H}_{2} \mathrm{O} \rightarrow 4 \mathrm{Fe}(\mathrm{OH})_{3}+8 \mathrm{CO}_{2}
$$




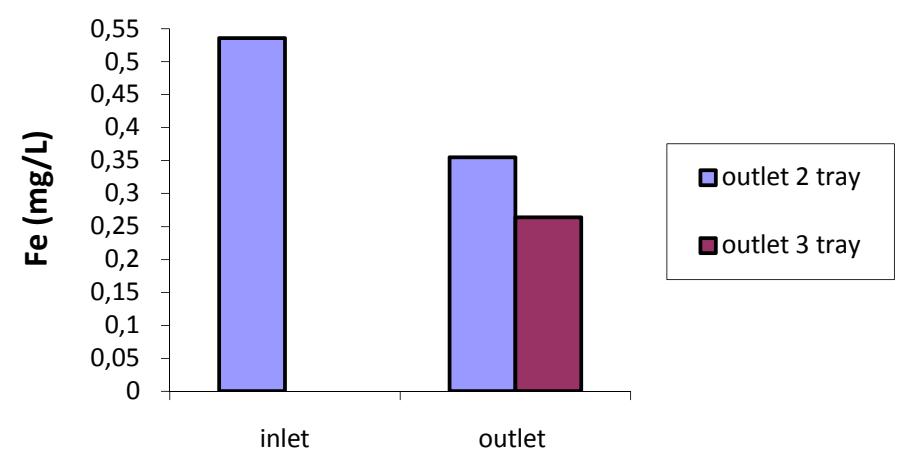

Gambar 2. Removal Fe pada tray tanpa media kontak

\section{- Removal Mn}

Pada Tabel 2 memperlihatkan bahwa pada jumlah tray sebanyak 2 tingkat memiliki efisiensi removal $\mathrm{Mn}^{2+}$ sebesar $5,41 \%$ atau sebanding dengan $0,002 \mathrm{mg} / \mathrm{L} \mathrm{Mn}$, sedangkan pada jumlah tray sebanyak 3 tingkat terjadi efisiensi removal $\mathrm{Mn}^{2+}$ sebesar 13,51\% atau sebanding dengan $0,005 \mathrm{mg} / \mathrm{L} \mathrm{Mn}$. Dapat diketahui bahwa kenaikan removal $\mathrm{Mn}^{2+}$ pada jumlah tray 3 tingkat memiliki nilai sebesar $8,10 \%$. Persamaan reaksi dari oksidasi mangan $\left(\mathrm{Mn}^{2+}\right)$ adalah sebagai berikut:

$$
2 \mathrm{MnSO}_{4}+2 \mathrm{Ca}\left(\mathrm{HCO}_{3}\right)_{2}+\mathrm{O}_{2} \rightarrow 2 \mathrm{MnO}_{2}+2 \mathrm{CaSO}_{4}+2 \mathrm{H}_{2} \mathrm{O}+4 \mathrm{CO}_{2}
$$

Berdasarkan reaksi di atas, mangan dalam bentuk $\mathrm{Mn}^{2+}$ dioksidasi oleh oksigen terlarut membentuk $\mathrm{Mn}^{4+}$ yang dapat mengendap.

Tabel 2. Data pengujian parameter Mn pada tray tanpa media kontak

\begin{tabular}{ccc}
\hline Jumlah Tray & Inlet $\left(\mathbf{m g} / \mathbf{L ~} \mathbf{M n}^{2+}\right)$ & Outlet $\left(\mathbf{m g} / \mathbf{L ~} \mathbf{M n}{ }^{\mathbf{4 +}}\right)$ \\
\hline outlet 2 tray & 0,037 & 0,035 \\
outlet 3 tray & 0,032 \\
\hline Sumber : Hasil Analisa Laboratorium &
\end{tabular}

Dibandingkan pada removal besi $\left(\mathrm{Fe}^{2+}\right)$, removal mangan $\left(\mathrm{Mn}^{2+}\right)$ memiliki efisiensi removal yang lebih kecil, hal ini dikarenakan proses oksidasi $\mathrm{Mn}^{2+}$ memiliki rentang $\mathrm{pH}$ yang sangat spesifik. Selain itu dengan adanya zat organik yang biasanya terdapat dalam air tanah, maka dapat mengganggu dalam proses oksidasi mangan $\left(\mathrm{Mn}^{2+}\right)$, karena mangan lebih mudah untuk berikatan dengan zat organik (organic compounds) dibandingkan besi, dan membentuk ikatan kompleks mangan-organik yang sulit untuk diendapkan, hanya dengan proses aerasi saja.

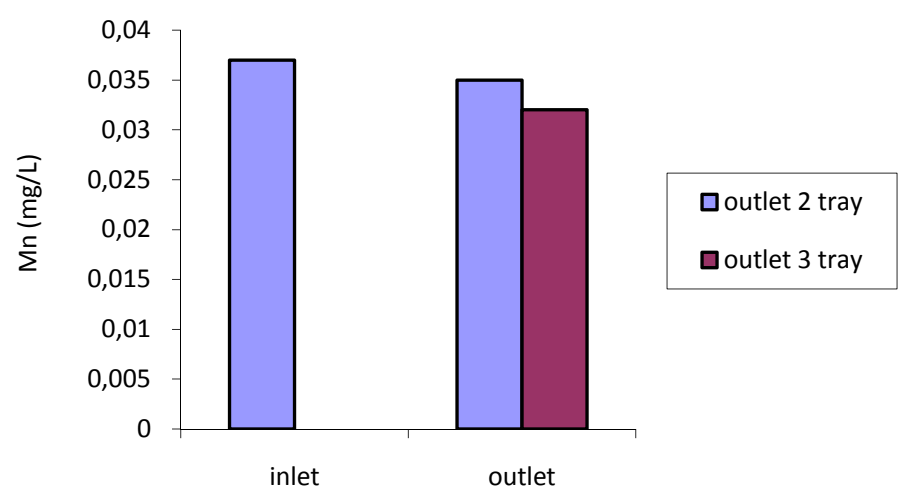

Gambar 3. Removal Mn pada tray tanpa media kontak

\section{- Removal Zat Organik}

Pada Tabel 3 menunjukkan bahwa efisiensi removal zat organik pada jumlah tray sebanyak 2 tingkat memiliki nilai sebesar $0,89 \%$ atau sebanding dengan $0,079 \mathrm{mg} / \mathrm{L} \mathrm{KMnO}_{4}$, sedangkan pada jumlah tray sebanyak 3 tingkat terjadi removal zat organik sebesar $2,52 \%$ atau sebanding dengan $0,223 \mathrm{mg} / \mathrm{L} \mathrm{KMnO}_{4}$. Terjadi peningkatan removal zat organik pada jumlah tray 3 tingkat yaitu sebesar $1,63 \%$. 
Tabel 3. Data pengujian parameter zat organik (PV) pada tray tanpa media kontak

\begin{tabular}{ccc}
\hline Jumlah Tray & Inlet $\left(\mathbf{m g} / \mathbf{L ~} \mathbf{K M n O}_{\mathbf{4}}\right)$ & Outlet $\left(\mathbf{m g} / \mathbf{L ~ K M n O} \mathbf{~}_{\mathbf{4}}\right)$ \\
\hline outlet 2 tray & \multirow{2}{*}{8,848} & 8,769 \\
outlet 3 tray & & 8,625 \\
\hline Sumber : Hasil Analisa Laboratorium & &
\end{tabular}

Zat organik (organic compounds) dalam air tanah biasanya berupa humic atau fulvic acid. Biasanya dalam air tanah komponen zat organik berikatan dengan besi $\left(\mathrm{Fe}^{2+}\right)$ dan mangan $\left(\mathrm{Mn}^{2+}\right)$ yang terlarut membentuk organik kompleks yang sulit untuk diendapkan. Walaupun dari sampel air yang dianalisa kandungan zat organiknya berada di bawah standar yang ditentukan $(<10 \mathrm{mg} / \mathrm{L})$, tetapi tetap perlu dipertimbangkan bahwa zat organik merupakan salah satu unsur penghambat dalam proses aerasi besi dan mangan.

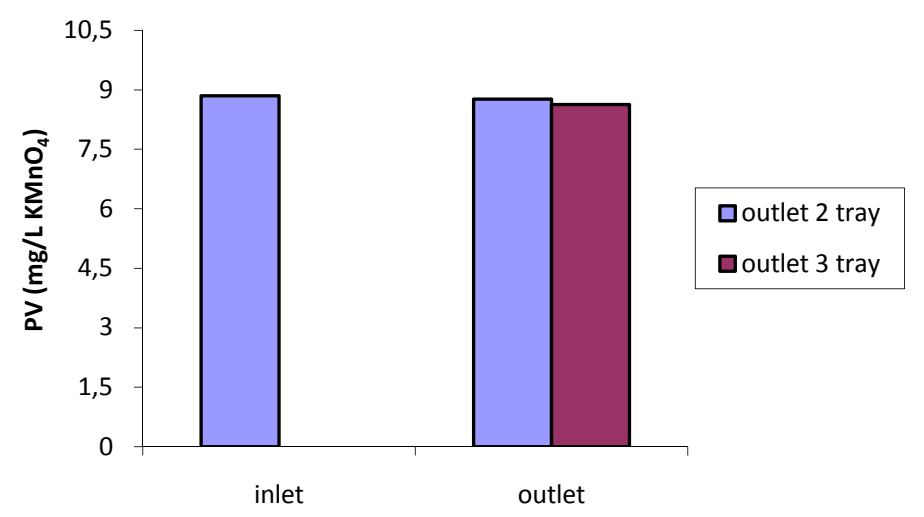

Gambar 4. Removal zat organik pada tray tanpa media kontak

\section{- pH, Temperatur, dan Kekeruhan}

Kondisi $\mathrm{pH}$, temperatur dan kekeruhan disajikan dalam satu tabel, yaitu Tabel 4, berdasarkan tabel tersebut dapat diketahui bahwa $\mathrm{pH}$ akan semakin meningkat seiring bertambahnya jumlah tray. Tingkatan $\mathrm{pH}$ merupakan salah satu faktor penting dalam reaksi oksidasi besi dan mangan, dimana semakin tinggi $\mathrm{pH}$, maka semakin tinggi pula efisiensi removalnya.

Tabel 4. Data $\mathrm{pH}$, suhu dan kekeruhan pada tray tanpa media kontak

\begin{tabular}{cccc}
\hline Keterangan & pH & Suhu $\left({ }^{\mathbf{0}} \mathbf{C}\right)$ & Kekeruhan \\
\hline inlet & 6,98 & 27,6 & 4,2 \\
oulet 2 tray & 7,06 & 27,8 & 3,0 \\
outlet 3 tray & 7,07 & 28 & 2,6 \\
\hline Sumber: Hasil Analisa Laboratorium & &
\end{tabular}

Sedangkan suhu/temperatur menggambarkan kondisi yang relatif konstan mulai awal proses (inlet) hingga akhir proses (outlet) aerasi. Untuk parameter kekeruhan menggambarkan kondisi yang relatif menurun seiring berkurangnya konsentrasi $\mathrm{Fe}, \mathrm{Mn}$, dan zat organik pada sampel air.

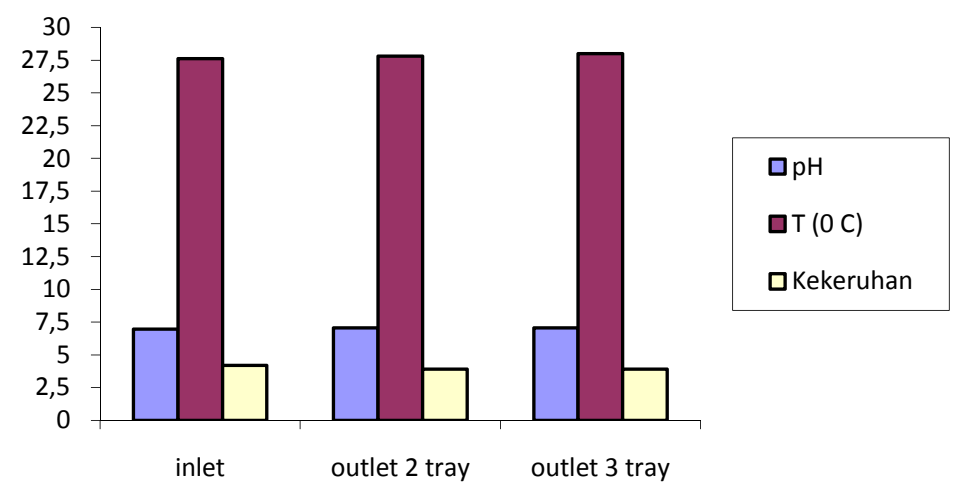

Gambar 5. pH, suhu, dan kekeruhan pada tray tanpa media kontak 


\section{- Hasil Analisa dan Pembahasan Tiap Parameter Sampel pada Media Tray Arang dan Batu}

a. Removal Fe

Dari Tabel 5 memperlihatkan bahwa pada jumlah tray sebanyak 2 tingkat dengan jenis media kontak batu, maka dapat diketahui bahwa removal $\mathrm{Fe}^{2+}$ memiliki efisiensi penurunan sebesar $67,72 \%$ atau sebanding dengan $0,363 \mathrm{mg} / \mathrm{L} \mathrm{Fe}$, sedangkan pada media yang sama dengan jumlah tray yang berbeda yaitu 3 tingkat terjadi removal $\mathrm{Fe}^{2+}$ sebesar $78,73 \%$ atau sebanding dengan $0,422 \mathrm{mg} / \mathrm{L} \mathrm{Fe}$., yaitu mengalami kenaikan sebesar $22,76 \%$.

Tabel 5. Data pengujian parameter Fe pada media arang dan batu

\begin{tabular}{cccc}
\hline \multirow{2}{*}{ Jumlah Tray } & \multirow{2}{*}{ Inlet $\left(\mathbf{m g} / \mathbf{L ~} \mathbf{F e}^{2+}\right)$} & \multicolumn{2}{c}{ Outlet media $\left(\mathbf{m g} / \mathbf{L ~} \mathbf{~ F e}^{3+}\right)$} \\
\cline { 3 - 4 } & & batu & arang \\
\hline 2 tray & \multirow{2}{*}{0,536} & 0,173 & 0,158 \\
3 tray & & 0,114 & 0,086 \\
\hline Sumber : Hasil Analisa Laboratorium & &
\end{tabular}

Hal ini membuktikan bahwa semakin lama air kontak dengan udara (oksigen), maka semakin maksimal pula proses aerasi yang terjadi, sehingga mengakibatkan semakin besar removal Fe-nya. Waktu kontak antar tray pada unit tray aerator memungkinkan air kontak dengan udara dalam kurun waktu tertentu dimana hal ini sangat berpengaruh terhadap jumlah oksigen terlarut (DO) yang tertransfer ke dalam air.

Berdasarkan Gambar 10 dapat diketahui bahwa dengan jenis media yang berbeda yaitu arang, maka akan menghasilkan removal $\mathrm{Fe}^{2+}$ yang berbeda pula. Pada jenis media ini removal $\mathrm{Fe}^{2+}$ memiliki removal sebesar $70,52 \%$ pada jumlah tray 2 tingkat atau sebanding dengan $0,378 \mathrm{mg} / \mathrm{L} \mathrm{Fe}$, dan $83,96 \%$ pada jumlah tray sebanyak 3 tingkat atau sebanding dengan $0,45 \mathrm{mg} / \mathrm{L} \mathrm{Fe}$.

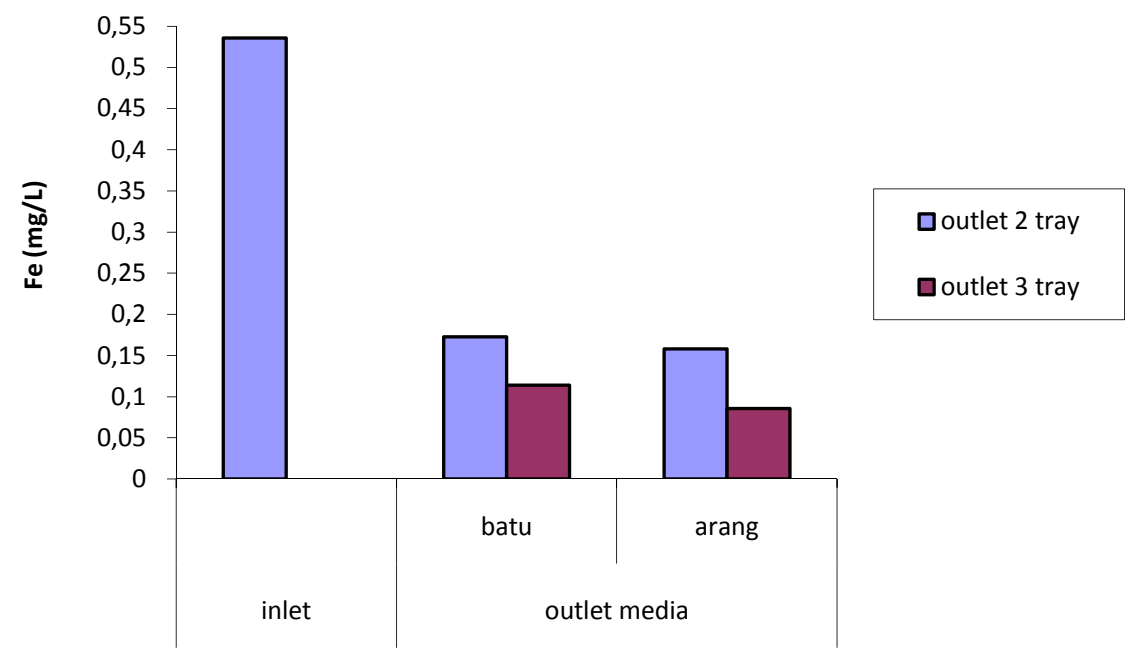

Gambar 6. Removal Fe pada media arang dan batu

Pada jenis media kontak arang lebih memungkinkan besi $\left(\mathrm{Fe}^{2+}\right)$ yang terlarut untuk mengalami proses oksidasi yang lebih sempurna dibanding jenis media batu. Hal ini disebabkan karena media arang mampu menaikkan $\mathrm{pH}$ air menjadi lebih basa, yang sangat baik untuk mengendapkan besi $\left(\mathrm{Fe}^{2+}\right)$. Selain itu media arang mempunyai permukaan yang terdiri dari banyak segi yang memungkinkan terjadinya peningkatan efisiensi pertukaran dan distribusi gas yang lebih besar. Sehingga oksigen terlarut akan lebih mudah tertransfer ke dalam air dan mengoksidasi besi $\left(\mathrm{Fe}^{2+}\right)$ menjadi besi $\left(\mathrm{Fe}^{3+}\right)$ yang dapat mengendap.

\section{- Removal Mn}

Dari Tabel 6 memperlihatkan bahwa pada jumlah tray sebanyak 2 tingkat dengan jenis media kontak batu, dapat diketahui bahwa removal $\mathrm{Mn}^{2+}$ memiliki removal sebesar $8,11 \%$ atau sebanding dengan $0,003 \mathrm{mg} / \mathrm{L} \mathrm{Mn}$, sedangkan pada media yang sama dengan jumlah tray yang berbeda yaitu 3 tingkat terjadi removal $\mathrm{Mn}^{2+}$ sebesar $24,32 \%$ yang sebanding dengan $0,009 \mathrm{mg} / \mathrm{L} \mathrm{Mn}$, atau mengalami kenaikan sebesar $16,21 \%$. 
Tabel 6. Data pengujian parameter Mn dengan media arang dan batu

\begin{tabular}{|c|c|c|c|}
\hline \multirow[b]{2}{*}{ Jumlah Tray } & \multirow{2}{*}{ Inlet (mg/L Mn ${ }^{2+}$ ) } & \multicolumn{2}{|c|}{ Outlet media $\left(\mathrm{mg} / \mathrm{L} \mathrm{Mn}^{4+}\right)$} \\
\hline & & batu & arang \\
\hline $\begin{array}{l}2 \text { tray } \\
3 \text { tray }\end{array}$ & 0,037 & $\begin{array}{l}0,034 \\
0,028\end{array}$ & $\begin{array}{l}0,030 \\
0,025\end{array}$ \\
\hline
\end{tabular}

Berdasarkan Gambar 7 dapat diketahui bahwa dengan jenis media yang berbeda yaitu media arang, maka akan menghasilkan removal $\mathrm{Mn}^{2+}$ yang berbeda pula. Pada jenis media ini removal $\mathrm{Mn}^{2+}$ mempunyai removal sebesar $18,92 \%$ pada jumlah tray 2 tingkat atau sebanding dengan $0,007 \mathrm{mg} / \mathrm{L} \mathrm{Mn}$, dan 32,43\% pada jumlah tray sebanyak 3 tingkat atau sebanding dengan $0,012 \mathrm{mg} / \mathrm{L} \mathrm{Mn}$.

Mangan yang terlarut dalam air tanah berada dalam bentuk $\mathrm{Mn}^{2+}$ yang sangat tidak larut, apabila dioksidasi, maka mangan $\left(\mathrm{Mn}^{2+}\right)$ akan berubah menjadi $\mathrm{Mn}^{4+}$ yang dapat mengendap. Persamaan reaksi oksidasi dari mangan adalah sebagai berikut:

$$
2 \mathrm{MnSO}_{4}+2 \mathrm{Ca}\left(\mathrm{HCO}_{3}\right)_{2}+\mathrm{O}_{2} \rightarrow 2 \mathrm{MnO}_{2}+2 \mathrm{CaSO}_{4}+2 \mathrm{H}_{2} \mathrm{O}+4 \mathrm{CO}_{2}
$$

Dari persamaan di atas dapat dilihat bahwa dengan adanya kesadahan air, yaitu terdapat $\mathrm{Ca}\left(\mathrm{HCO}_{3}\right)_{2}$ dalam air tanah, dapat menyebabkan terjadinya pengendapan mangan $\left(\mathrm{Mn}^{2+}\right)$ yang lebih efektif, karena suasana air cenderung bersifat basa $(\mathrm{pH}>7)$ yang ditimbulkan karena adanya unsur $\mathrm{Ca}^{2+}$ sebagai salah satu mineral pembentuk oksida basa.

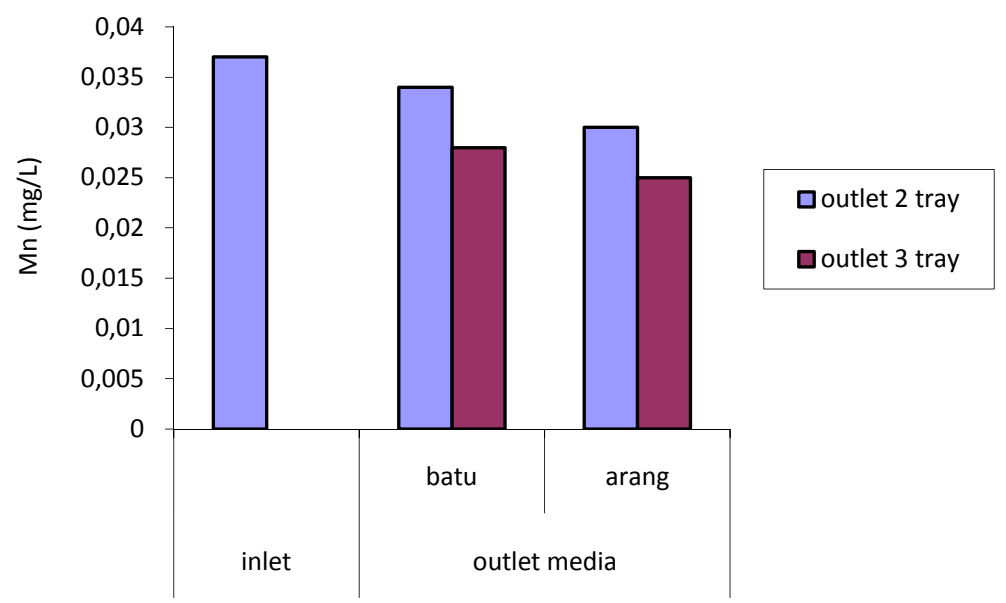

Gambar 7. Removal Mn pada media arang dan batu

\section{- Removal Zat Organik}

Dari Tabel 7 memperlihatkan bahwa pada jumlah tray sebanyak 2 tingkat dengan jenis media kontak batu, maka dapat diketahui bahwa removal zat organik memiliki removal sebesar 21,43\% atau sebanding dengan 1,896 $\mathrm{mg} / \mathrm{L} \mathrm{KMnO}_{4}$, sedangkan pada media yang sama dengan jumlah tray yang berbeda yaitu 3 tingkat terjadi removal zat organik sebesar $28,57 \%$ atau sebanding dengan $2,528 \mathrm{mg} / \mathrm{L} \mathrm{KMnO}_{4}$.

Tabel 7. Data pengujian parameter PVpada media arang dan batu

\begin{tabular}{|c|c|c|c|}
\hline \multirow[b]{2}{*}{ Jumlah Tray } & \multirow{2}{*}{ Inlet $\left(\mathrm{mg} / \mathrm{L} \mathrm{KMnO} \mathrm{KM}_{4}\right)$} & \multicolumn{2}{|c|}{ Outlet media (mg/L KMnO$\left.{ }_{4}\right)$} \\
\hline & & batu & arang \\
\hline 2 tray & 8,848 & 6,952 & 7,268 \\
\hline 3 tray & 8,848 & 6,320 & 6,952 \\
\hline
\end{tabular}

Sedangkan pada jenis media kontak arang, diketahui bahwa pada jumlah tray sebanyak 2 tingkat memiliki efisiensi removal zat organik sebesar $17,86 \%$ atau sebanding dengan $1,58 \mathrm{mg} / \mathrm{L} \mathrm{KMnO}{ }_{4}$ dan pada jumlah tray sebanyak 3 tingkat diperoleh efisiensi removal zat organik sebesar 21,43\% atau sebanding dengan 1,896 mg/L $\mathrm{KMnO}_{4}$.

Jumlah zat organik yang sedikit atau rendah dalam air tanah meningkatkan efisiensi pengolahan dalam proses oksidasi removal besi dan mangan. Dalam air tanah biasanya $\mathrm{Fe}^{2+}$ berikatan dengan zat organik membentuk ikatan kompleks besi-organik yang sulit diendapkan walaupun telah melalui proses aerasi, hal inilah yang menyebabkan proses aerasi berlangsung kurang efektif. 


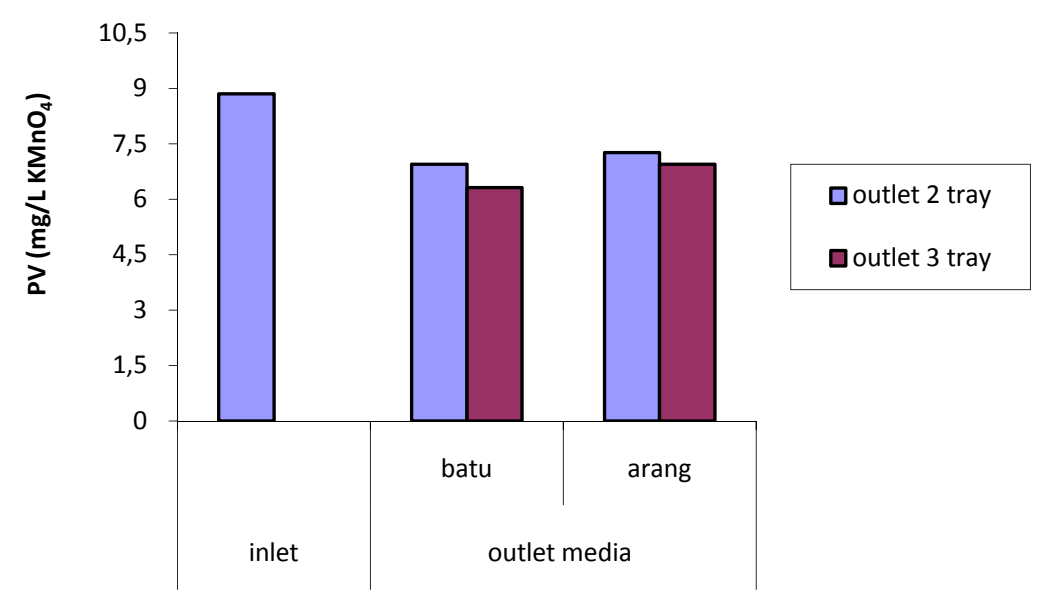

Gambar 8. Removal zat organik pada media arang dan batu

\section{- $\quad$ pH. Temperatur, dan Kekeruhan}

Kondisi $\mathrm{pH}$, temperatur dan kekeruhan disajikan dalam satu tabel, yaitu Tabel 8, berdasarkan tabel tersebut dapat diketahui bahwa $\mathrm{pH}$ pada media kontak arang mempunyai kecenderungan nilai $\mathrm{pH}$ yang lebih tinggi bila dibandingkan dengan $\mathrm{pH}$ pada media kontak batu, hal inilah yang membuat reaksi oksidasi besi dan mangan pada media arang berjalan jauh lebih efektif dibandingkan dengan proses oksidasi pada media batu.

Tabel 8. Data $\mathrm{pH}$, suhu dan kekeruhan pada media arang dan batu

\begin{tabular}{clccc}
\hline \multicolumn{2}{c}{ Keterangan } & pH & Suhu $\left(^{\mathbf{0}} \mathbf{C}\right)$ & Kekeruhan \\
\hline inlet & & 6,98 & 27,6 & 4,2 \\
\hline \multirow{2}{*}{ oulet 2 tray } & media batu & 7,11 & 28,2 & 2,2 \\
& media arang & 7,19 & 28,3 & 1,8 \\
\hline \multirow{2}{*}{ outlet 3 tray } & media batu & 7,14 & 28,1 & 1,9 \\
& media arang & 7,21 & 28,2 & 1,5 \\
\hline \multicolumn{2}{l}{ Sumber : Hasil Analisa Laboratorium } & &
\end{tabular}

Berdasarkan Gambar 9 diketahui bahwa suhu/temperatur menggambarkan kondisi yang relatif konstan (tidak mengalami peningkatan yang signifikan) mulai awal proses (inlet) hingga akhir proses (outlet) aerasi. Sedangkan untuk parameter kekeruhan pada penelitian penurunan kadar besi $\left(\mathrm{Fe}^{2+}\right)$ dan mangan $\left(\mathrm{Mn}^{2+}\right)$ pada air tanah PDAM Kota Blitar ini digunakan untuk mengetahui korelasi antara konsentrasi besi, mangan dan zat organik yang terdapat dalam air tanah dengan kekeruhan yang ditimbulkan pada air baku.

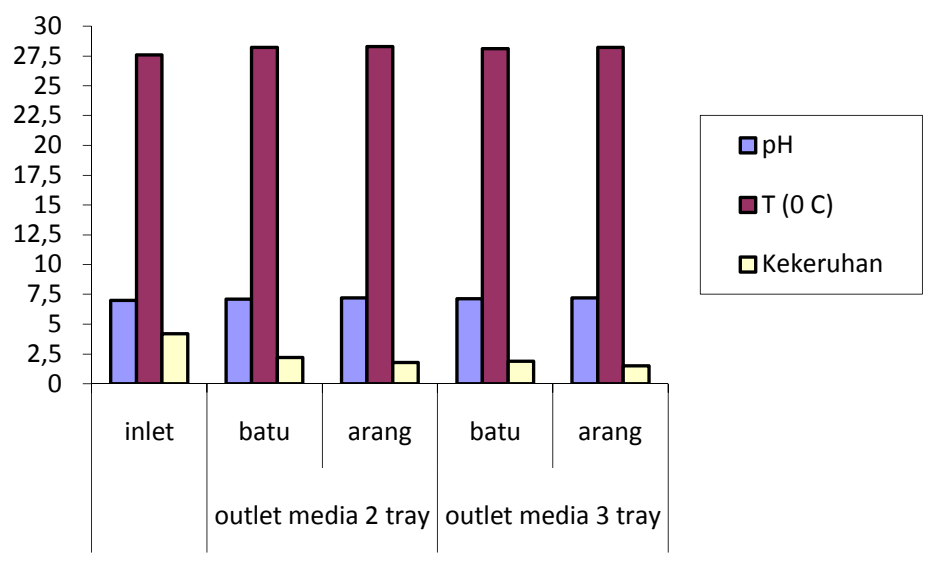

Gambar 9. pH, suhu, dan kekeruhan pada media arang dan batu 


\section{SIMPULAN}

Berdasarkan analisa data dan pembahasan, maka dapat ditarik simpulan sebagai berikut, efisiensi removal tertinggi pada tray tanpa media kontak diperoleh dari hasil variasi dengan menggunakan tray sejumlah 3 tingkat dengan efisiensi removal besi sebesar 50,75\%, mangan sebesar $15,31 \%$, dan zat organik sebesar 2,52\%. Sedangkan pada tray aerator dengan adanya penambahan media kontak, yaitu media batu dan arang, efisiensi proses tertinggi diperoleh pada variasi jumlah tray 3 tingkat dengan media kontak arang diperoleh efisiensi removal besi sebesar $83,96 \%$, mangan sebesar $32,43 \%$, dan zat organik sebesar $21,43 \%$. Dengan adanya penambahan media kontak pada unit tray aerator, efisiensi proses aerasi dalam menurunkan kandungan besi $\left(\mathrm{Fe}^{2+}\right)$ terlarut meningkat sebesar $33,21 \%$, kandungan mangan $\left(\mathrm{Mn}^{2+}\right)$ sebesar $17,12 \%$, dan zat organik sebesar $18,91 \%$.

\section{DAFTAR PUSTAKA}

[1] Al-Laila, M. Anis. 1978. “Water Supply Engineering Design”. An Arbor Science, USA.

[2] Alaerts, G dan Sumestri, S. 1987. "Metodologi Penelitian Air". Usaha Nasional, Surabaya.

[3] AWWA \& ASCE. 1990. "Water Treatment Plant Design”, $2^{\text {nd }}$ Edition. Mc Graw Hill Book Company Inc., New York, USA.

[4] David, G. Stevenson. 1998. "Water Treatment Unit Process". Imperial ollege Press.

[5] Erness, W. Steel. 1960. "Water Supply and Sewerage”. Mc Graw Hill Book ompany In., New York, USA.

[6] Harry, Jue. 2003. "Water Quality Report : Important Information about the Safety of Your Drinking Water". (online). (http://www.awwa.org).

[7] Kawamura, Susumu. 1991. "Integrated Design of Water Treatment Facilities”. John Wiley and Sons, New York, USA.

[8] Larry, D. Benefield and Afford, W. Randal. 1982. "Process Chemistry of Water and Wastewater Engineering Treatment”. Prentice Hall In., New Jersey.

[9] Reynold, Tom D. 1982. "Unit Operations and Process in Environmental Engineering". Books/Cole Engineering Division, Monterey, California.

[10] Qasim, R. Syed, et al. 2000. “Waterworks Engineering, Planning, Design, and Operations”. CBS International Editon. 